\title{
The geo-strategic implications of China's growth
}

\author{
Hugh White
}

\section{Geo-strategy returns}

In the 20 years since the Berlin Wall fell, the common working assumption among policymakers and analysts of international affairs alike has been that the end of the Cold War marked not just the end of a particular geo-strategic episode, but the end of an era in which geo-strategy as traditionally conceived-focusing on strategic competition between states and especially between major powers - played a significant role in shaping the international system.

Many compelling arguments supported this idea. In an era without the sharp ideological divisions of the twentieth century, it was argued, there would be little to disagree about or compete over. In an era of globalisation, the disruption to trade and other forms of communication caused by competition and conflict would be too costly to contemplate. In an era of unipolarity, the United States' overwhelming military preponderance would deter any government from challenging the US-led global order, which it was clearly committed to perpetuate. And, after 9/11, non-state actors such as terrorists, and the weak and rogue states that allowed them to flourish, seemed much more dangerous and claimed most of the political and intellectual attention previously devoted to geo-strategic concerns. It became commonplace to assert that in the new century serious challenges to the global order arose not from traditional strategic competition but from the toxic combination of terrorists, weak and rogue states and weapons of mass destruction.

This set of ideas has by no means faded away. It remains central, for example, to the views of US Secretary of Defence, Robert Gates (2009), about America's future defence needs. In the past year or two, however, it has been challenged by authors who have started to pay attention to the way in which shifts in the relative power of states could produce pressures 
for change in the global order of a quite different kind, and potentially of much greater magnitude and significance, than those posed by non-state actors and weak and rogue states. ${ }^{1}$ They argue that economic growth in many countries around the world - though very much a product of the US-led globalised order of recent decades - could nonetheless undermine that order because it will produce changes in relative power among states, which the order will struggle to accommodate.

This argument is supported by some simple but powerful insights. First, in a globalised world, states still seem to act very much as states always have, and though their actions do not necessarily conform to the dire predictions of the hardline realists, ${ }^{2}$ nor do they invariably reflect an unwaveringly rational commitment to enlightened mutual self-interest. Pride and fear still shape state's actions, primarily because they shape citizens' expectations of their states and their leaders. In a globalised world, states still act as states always have because most citizens still seem to relate to their states very much as they always have: in a deeply emotional and tribal way. Nationalism in it various forms remains as strong as ever, not just among the peoples of emerging nations but among those of established powers.

Second, the nature and scale of the terrorist threat, though still serious, is now seen as less apocalyptic than it was in the first shock after $9 / 11$. This opens political and intellectual space to explore these other challenges to international order and it undermines hopes that any emerging geostrategic competition might be subsumed in the common cause of fighting jihadist terrorism (Bell 2008). Third, it has become clearer that in a globalised world, interdependence cuts two ways, constraining the United States as well as potential challengers to the international order. It transpires that the United States cannot act with as much freedom as some expected to impose its will on an unruly world, because it too will suffer so badly from any resulting disruption. Fourth, the past decade has brought a more sober and realistic understanding of the limits to US military power. It is now clear that the United States cannot use force as easily and cheaply as many had assumed to uphold its vision of global order.

For all these reasons, geo-strategy is back. We are again exploring how the international order - the set of understandings and expectations that shapes relationships between states - is formed by the perceptions and realties of power, and especially how changes in relative power affect the 
workings of the international order. Moreover, after a period during the Cold War in which geo-strategic calculations were based more on military than on economic factors, we are rediscovering the centrality of economic power as the key driver of geo-strategic relationships. There is a simple reason for this: we are living through a period of remarkable economic transformation. The number of people engaged in the modern global economy has doubled in the past two decades and could double again in the next few decades. This has produced by far the largest increase in economic activity of any comparable period in history, as huge populations around the world have moved from low-productivity to high-productivity forms of work. ${ }^{3}$ This in turn is driving shifts in relative economic weight of a scale and speed that we have not seen for many decades, if ever. Policymakers and analysts are starting to realise that if the trends of recent decades persist, the United States will not retain the unchallengeable economic primacy it enjoyed throughout the past century. In this century, there are likely to be many very strong states that the United States will have to deal with.

Much of the analyses of these trends, including those cited earlier, explore the general implications of the rising power of the whole class of emerging economies for the international order. ${ }^{4}$ This is useful as far as it goes, but exploring the geo-strategic consequences of the emerging economies as a group runs the risk of understating the significance of the most important of them. China's growing economic weight is far more significant than that of any other emerging power in its implications for future international order-because it is by far the largest of the emerging economies and because its growing power so profoundly affects the regional order in North-East Asia, which is by far the most important focus of geo-strategic competition on Earth.

It is easy to underestimate the geo-strategic implications for the international order of China's growing economic weight because so little seems to have happened so far. China's economy has grown strongly and steadily for more than 30 years and its relative economic strength has grown remarkably, yet its place in the international order has not so far changed nearly as radically. It is tempting to conclude that China's economic growth has little geo-strategic impact. This assumes, however, that geo-strategic change follows steadily and smoothly as economic weight shifts. That is not necessarily so. The geo-strategic consequences of economic change can be 'sticky': the status quo can persist for years as economic weight shifts and then fall swiftly when the pressure becomes 
too great to bear. East Asia's stable strategic order has persisted through several decades of fast Chinese growth, but that does not necessarily mean no changes are in store. It could mean that change, when it comes, is swifter and more disruptive for having been delayed.

\section{China grows}

The tipping point might not be far away. For several decades, it has been relatively easy to overlook the strategic implications of China's growing economic weight, but in the past couple of years attention has started to focus on an unmistakable and fast-approaching geo-strategic milepost: the point at which China overtakes the United States to become the largest economy in the world. Statistically, it has been clear for a long time that if the trends of recent decades are sustained, China's output will overtake the United States' some time in the next few decades, but only in the past year or two has this become an imminent and inescapable probability. Only in the past year or two have strategic policymakers and analysts started to take notice.

The Australian Government's Defence White Paper released in May 2009 predicted that on some measures China's economy could overtake the United States' to become the largest in the world by about 2020 (Commonwealth of Australia 2009:34, para. 4.23). By 'some measures', the White Paper presumably meant purchasing power parity (PPP), because the date at which China's gross domestic product (GDP) in market exchange rate terms overtakes the United States' is at present much more remote, and PPP is clearly the more relevant measure of economic weight for geostrategy. ${ }^{5}$ The date of 2020 is at the closer end of the range of credible crossover dates. The middle of the range of estimates is probably closer to 2030, but from a geo-strategic point of view, a decade here or there is not very important. What matters is the recognition that the United States will probably loose the advantage in sheer economic scale that it has enjoyed ever since it rose to global power well within the time frames of today's strategic and defence policymakers. This probability is no longer a statistical curiosity but an active factor in shaping policy.

Of course, this prediction could prove false. China's economic growth might falter for one or more of a wide range of reasons - social, economic, political, environmental or indeed strategic. After three decades of rapid growth, however, sustained by continual adaptation and reform within China, there is no compelling reason to assume that China cannot sustain 
growth in the next three decades at rates sufficient to overtake the United States in output. And although it is too early to be sure, it seems probable that the global financial crisis will, if anything, accelerate the power shift from the United States to China. If or when it happens, China's ascent to the leading position in the global economy will mark the end of 130 years of US economic primacy.

Why does that matter to geo-strategy? The connection between economic and strategic power is complex in detail, but historical evidence suggests that it is simple in essence: in the modern era, economic scale is the necessary and sufficient precondition for strategic weight. In the nineteenth century, the United Kingdom's global maritime primacy lasted as long as its economic primacy - and not much longer. The United States took its place as the world's strongest strategic player soon after it displaced the United Kingdom as the world's biggest economy, in the 1880s. It is possible that the foundations of US strategic power lie elsewhere than in its economic strength, but one must at least note that it has never exercised any significant strategic power beyond its own immediate region except when it has commanded the world's largest economy.

Some would argue that this is too simple. The Central Intelligence Agency (CIA) in its November 2008 report, Global Trends: 2025 report, used a compound measure of national power incorporating GDP, defence spending, population and technology. It is not clear how valid this compound measure is over longer time frames, because in the long run, all other things being equal, defence spending and technological strength will tend to follow economic weight. In the short term, however-the next two or three decades anyway - it would certainly be wrong to assume that as China overtakes the United States in economic output it will necessarily assume its position as the global superpower. The United States will continue to enjoy a significant advantage over China in many other aspects of power-including the soft power of culture and the hard power of armed force- - because while these kinds of power are no doubt based ultimately on economic power, their development can lag economic growth by decades. China is establishing the long-term sources of these different kinds of power through immense investment in education. It will be some decades, however, before it can challenge the United States-for example, in its capacity to project substantial military force to any corner of the globe. It will be a long time, if ever, before China could emulate the United States' position in recent decades as the world's leading power. 


\section{Primacy fades}

China does not, however, have to replace the United States as the global hyper-power in order to overturn the US-led global order of recent decades. China's growing power can reshape the global order by challenging the United States' position in the new century's economic and strategic centre of gravity: Asia. China's growing economic weight will erode US strategic primacy in the Western Pacific-indeed, it is already doing so. This process has political, diplomatic, economic and military aspects. Others have written about the ways in which China has increased its diplomatic and economic influence in Asia in the past decade (Osbourne 2007). Here, I want to just touch on the specific military aspects of the power transition now under way in Asia. Economic strength is the foundation of strategic power, but military capability is its most direct and tangible expression, and economic growth shapes geo-strategic affairs most directly by supporting expanded military capabilities. The extent to which growing Chinese military capabilities reflect the geo-strategic significance of China's growing economic weight is often underestimated because US defence spending remains so much larger, and its aggregate capabilities remain so far superior. That, however, misses the point in two ways. First, China does not need to compete with the United States globally in order to erode US primacy in Asia. Second, China does not need to be able to emulate the United States in military capability, but simply limit US options. In both these respects, the military-strategic competition between the United States and China is asymmetrical, in ways that benefit China.

In military terms, American strategic primacy in Asia has been based on its capacity to exert what naval strategists call 'sea control' over the Western Pacific. Sea control is the ability to use the sea, especially to project force. The United States' military position in Asia has depended primarily on its capacity to project force by deploying aircraft carriers and amphibious forces anywhere in the Western Pacific with relatively low risk. Now, however, US sea control is slipping away as China develops the capacity to deny important areas of the Western Pacific-especially those closest to China - to the US Navy's surface fleet.

This process has been going on for some time. China's military priorities started to shift from continental to maritime capabilities after the collapse of the Soviet Union alleviated what had been its most pressing strategic risk. China started to acquire highly capable air and naval systems from its former Soviet adversaries in the early 1990s, and this process has accelerated since 1996. In that year, the United States deployed carriers 
to the waters around Taiwan in a show of support for Taipei after China used missile tests to intimidate Taiwanese voters in that year's presidential election. Historians might judge that this was the last time in which the United States could exercise the assured sea control that once characterised and in important ways constituted its strategic primacy in Asia. Since then, Chinese submarine forces have improved markedly, to the point where they now pose a significant threat to US carriers and other surface ships, and China has also reportedly developed more exotic sea-denial capabilities, including ballistic missiles capable of hitting aircraft carriers at long range. The costs and risks to the United States of deploying carriers or amphibious forces to the waters around Taiwan or elsewhere in China's extended maritime approaches - including around Korea and Japanhave already increased sharply. This limits US options and raises the threshold for intervention to the point that naval power projection might no longer be a viable military option for the United States in any future confrontation with China unless absolutely vital US interests are at stake. Moreover, the trends clearly suggest that this problem will intensify. Ten years from now, the costs and risks will be even higher, further raising the threshold of US military intervention in any strategic crisis in East Asia.

Of course, during the Cold War, the United States faced formidable Soviet sea-denial forces in the Western Pacific, but in those days it was clear that US strategic interests vis-a-vis the Soviet Union were so vital that the United States would accept huge strategic costs and risks to defend them. Since the Cold War, US interests in Asia are less compelling. Since 1989, successive US administrations have persuasively affirmed continued US interests and engagement in Asia, but all interests have their limits, and it is clear that nothing in Asia matters to the United States today as much as containing the Soviet Union did - unless it is to prevent the appearance of another strategic 'peer competitor'.

That leads us to the question of how the United States responds to China's challenge. First, however, we need to explore how serious that challenge is. The arguments presented so far suggest that the economic foundations and military dimensions of US primacy in Asia have already been significantly eroded as China's economy has grown, and will continue to do so in coming years. Some will argue, however, that the true foundations of US primacy are not to be found in its armed forces or its economic output, but in its ideas, values and institutions. This is a hard argument to evaluate. Clearly, many of what Americans regard as American values are highly attractive to many others around the world, including 
in Asia. The universality of these values, however, which US leaders so often assert, ${ }^{6}$ tends to undermine their belief that they are distinctively American and that global support for them constitutes any substantial adjunct to US power. In the end, the argument that American values support US power probably presupposes that a significant proportion of the world's population believes that only in a global order dominated by the United States can those values flourish. There could be some truth in the basic proposition, but there is little evidence that many people in places such as China see things this way. They certainly seek many of the values that the United States champions, but they do not necessarily believe that only US global leadership can deliver them.

Of course, anyone who foreshadows the eclipse of US primacy in Asia must be uncomfortably aware that such predictions have been made and proved wrong many times before. Previous predictions, however, have been made at times of transient US uncertainty and have underestimated the country's remarkable power of reinvention and innovation. This time, it is different, because what threatens US primacy in Asia is not the grave but inevitably transient strategic and economic problems that beset the new president, but something much deeper. US primacy in Asia is not challenged by US weakness but by China's strength. This is new. Never before has US primacy been challenged at its most fundamental sourceby its eclipse as the world's most productive economy.

The source of that challenge runs very deep. In a sense, it began a century ago, as the Chinese toppled the moribund empire and started trying to build a modern state that could regain China's traditional place in the world. That proved to be a long and tragic struggle, but today's China is the result. By adopting so many (though not all) of the economic, political, institutional and technological ideas that have made the rich world's workers so productive in the past two centuries, China is now within sight of regaining its position as the world's biggest economy, which its huge population secured for it until the Industrial Revolution boosted the United Kingdom's productivity so spectacularly. As China emulates the productivity of a modern advanced economy, its sheer scale ensures that it will end up producing more. In geo-strategy, destiny is not so much demographics alone, but the combination of demographics and labour productivity

For Americans, this prompts the uncomfortable speculation that US power has not resulted from any special quality of their country. Instead, it is a product of the simple circumstance that the United States has 
remained for more than a century the most populous country to have consistently maintained the productivity-promoting practices, policies and institutions that first appeared with the Industrial Revolution. It also enjoyed the advantage of being spared the worst ravages of war. Now, after 30 years of peace and stability during which market economics have been supported by relatively stable government at home and peace abroad, China is doing what the United States did, but on an even bigger scale.

\section{Asia transforms}

What does all this mean for Asia? China's economic growth has profound geo-strategic implications because it challenges the United States' economic primacy, which has been the foundation of US strategic primacy, which has in turn been the foundation of the international order that has kept East Asia so peaceful for nearly four decades. Since the early 1970s, Asia has enjoyed the most prosperous and cooperative period in its long history, and in retrospect, it seems clear that the main cause has been the emergence of a set of stable and uncompetitive strategic relationships between Asia's most powerful states: the United States, China and Japan. Former US President Richard Nixon's visit to China initiated this period, because it marked the point at which US strategic primacy in Asia ceased to be opposed actively by China. Instead, a stable triangular power balance evolved in which China and Japan both accepted US primacy in return for the assurance it gave them in relation to one another and to the Soviet Union. As a result, US failure in Vietnam was followed by decades of uncontested primacy, which created the necessary conditions for so much else: the success of the Association of South-East Asian Nations (ASEAN); Indochina's recovery; the economic growth of Japan, South Korea, Taiwan and China; Asia's regional integration; and Australia's enmeshment in Asia. $^{7}$

As the economic foundation of the United States' primacy erodes, the Asian order that has been built on it will change. There is no reason to expect that China will continue to accept US primacy as the basis of the regional order in Asia while its own power approaches and exceeds the United States', and it therefore no longer need rely on the United States for assurance against Russia and Japan. Of course, China will want Asia to remain peaceful and harmonious, but it will not see US primacy as necessary for that. It will see increased Chinese power and influence in Asia as perfectly compatible with the perpetuation of a stable and 
cooperative regional order. Whether that proves to be correct or not will depend on how China chooses to use its growing power, and on how others respond.

It is hard to get a clear picture of Chinese ideas about its future role in Asia. China's own history offers little guidance, because it has never before exercised great power in an Asia of modern nation-states. In one view, Beijing might be content to establish a modest sphere of influence over its immediate periphery, but its immediate periphery includes Japan, so even this apparently modest goal would require it to establish clear primacy over the other major Asian power. It seems inevitable therefore that China will aim for a wider leadership role in Asia; but of what kind? There is no evidence that Beijing seeks the kind of 'hard' militarised hegemony that we associate with the communist strategic policies of Joseph Stalin and Leonid Brezhnev. Certainly, Chinese military developments do not support such fears. It is much more likely that China will seek a kind of 'soft' hegemony, comparable with the leadership that the United States exercises in the Western hemisphere under the Monroe Doctrine. As keen students of history, the Chinese would understand that the Monroe Doctrine has delivered the United States substantial economic, political and strategic benefits at relatively low cost for a very long time. It is hard to see why they should want anything more - but it is also not clear why, as its power grows, China would aim for anything less.

Much will therefore depend on how the United States responds to China's rise. 'Monroe-style' primacy cannot be shared, so for China to achieve this ambition, the United States would need-perhaps very gradually - to concede its strategic position in Asia to China and withdraw. That seems on the face of it rather unlikely - as Secretary of State, Hilary Clinton (2009), said recently, 'The United States is not ceding the Pacific to anyone' - but it cannot be completely discounted. Two other outcomes are, however, more probable: either the United States elects to share power with China or it tries to maintain primacy by contesting China's challenge. Whichever option the United States takes, Asia's international order emerges very different from the one that has served the region so well for the past almost four decades. Moreover, any of them would be likely to carry significantly greater risks of strategic competition and even conflict between Asia's major powers than we have seen since the Vietnam War. US withdrawal would substantially increase the intensity of strategic competition between China and Japan. A US decision to contest China's challenge would inevitably increase strategic competition between them 
and probably lead to a polarisation of the region into US and Chinese camps. Even a decision by the United States to share power with China would entail a risky and complex negotiation involving not only these two powers but Japan and eventually India to establish what would in effect be a concert of Asia's major powers. ${ }^{8}$

Unfortunately, the most risky of these outcomes is also the most probable. To share power with China under some kind of concert arrangement would require the United States to treat China as an equal in every respect of international power: acknowledging unreservedly the legitimacy of its political system, its international interests even when they clash with the United States' and-within the limits set by the UN Charter-the legitimacy of China using its armed forces to protect those interests. It does not seem at all likely that the United States will in fact be willing to concede this much to China, and it is unlikely to do so unless and until it is brought face-to-face with the costs and risks of any alternative way of responding to China's growing power. There is an element of denial in US approaches to the strategic implications of China's rise: a reluctance to accept and address the direct implications of well-established trends. The result is an unexamined assumption that for the United States, retaining primacy in Asia is the only possible strategic objective. US debates have not yet, however, faced the question of how far they are willing to go and how much they are willing to spend to preserve primacy against a country that can match the United States in economic output.

China also has hard choices to make if it is to help build a powersharing 'concert of Asia'. It will have to forgo aspirations to lead Asia itself and accept that the United States will remain a major player-and a major constraint on China's freedom of action. Even harder, perhaps, would be the need for China to accept Japan as an equal participant in Asia's strategic affairs. Japan is too strong to be left out of the top tier of any new Asian order and it is hard to see how it could remain a strategic client of the United States within a concert of Asia. The cooperative USChina relationship that would be required for a concert of Asia to work would be too close for Japan to be comfortable about relying on the United States for protection from China's power. The stronger Beijing becomes, and the more important to Washington it grows, the less sure Tokyo can be that Washington will always put Japanese interests ahead of Beijing's. Unless Tokyo can establish an independent strategic position, with all that that entails, it can therefore be expected to exercise a strong and probably effective veto over US-China strategic accommodation. 
Overcoming all these obstacles would take remarkable diplomacy and statecraft from all three major powers. That makes it unlikely that we will see a new concert of Asia that will accommodate China's growing economic and strategic weight. More probably, we will see a steady increase in strategic competition between the United States and China. It is important to recognise that this is not necessarily China's fault. China's growth is certainly driving geo-strategic change in Asia, but how that change unfolds and what it means for Asia depend as much on how others countries respond as on how China seeks to use this power.

\section{Hard choices}

It is tempting to see the challenges to Asia's geo-strategic order posed by China's growing economic weight as a problem for the next generation of policymakers, or indeed to deny that it is a problem at all. The first response seems to be exemplified by Australia's new Defence White Paper, which while acknowledging, as we have seen, the speed and significance of China's economic rise, nonetheless defers any serious policy response to the 2020s and beyond. The second response typifies that of most in the US policy community, who either assume that China's economic growth will stall before it can overtake the United States or that US primacy can somehow be sustained - by soft or hard power or by both-long after the economic power that underpins it has been overtaken.

The reasons for these evasions are plain. Acknowledging the geo-strategic implications of Asia's economic transformation impels policymakers and analysts towards momentous and profoundly difficult choices. For Americans, the choice is between order and primacy. For decades, there has been no such choice, because US primacy has been the essential condition of Asia's stability. In future, however, the United States might be able to sustain primacy only at the expense of order. An effort to maintain US primacy would involve the construction of a coalition of US allies to contest the Chinese challenge to the United States' position, of which the trilateral alignment of the United States, Japan and Australiaand the quadrilateral alignment involving India as well-can be seen as the first rough drafts. Such moves risk drawing Asia towards a divided future dominated by strategic competition between armed camps. The costs of such a future in terms of lost opportunities for trade, investment and integration of all kinds are potentially immense, and the risks of allout conflict are significant too. It is easy to mount arguments as to why 
Americans would prefer not to share power in Asia with China; it is harder to explain why the costs and risks of doing so outweigh the costs and risks of entering sustained strategic competition with a country of China's immense strategic potential. History might be a poor guide here: China is not the Soviet Union. The United States cannot be sure that it would win such a competition, or that victory in such a competition, if it could be attained, would be worth the cost.

The United States' allies in Asia likewise face tough choices once they confront the geo-strategic implications of China's rise. For Australia, the choices are especially momentous, because the eclipse of US primacy would mark not just the end of the post-Vietnam order that has kept Asia so peaceful and Australia so secure in recent decades. It would mark the end of the Anglo-Saxon maritime domination of Asia, which has been seen by Australians as the necessary and sufficient condition for their security since a colony was founded at Sydney Cove in 1788. Australians need to decide whether they should follow their traditions and instincts by urging the United States to contest the Chinese challenge to this deepest foundation of Australian security, or whether they owe the forces of history and encourage the United States to accept a different, lesser but still critical role in Asia as a balancer of China in a concert of equals. And if, regardless of what they say, the United States decides to contest China's challenge, Australians would need to decide whether they should support the United States in doing so or slide towards an uneasy and insecure neutrality. Either way, Australia faces much greater strategic risks than it has been used to since the 1960s.

\section{References}

Bell, C. 2008, The End of the Vasco da Gama Era, The Lowy Institute, Sydney.

Castles, I. 2008, 'PPP is not "basically a con"' , East Asia Forum, 3 December 2008, $<$ www.eastasiaforum.org/2008/12/03/ppp-is-not-basically-a-con/>

Central Intelligence Agency (CIA) 2008, Global Trends: 2025 report, November, Central Intelligence Agency, Washington, DC, <http://www.dni.gov/nic/ PDF_2025/2025_Global_Trends_Final_Report.pdf $>$

Clinton, H. 2009, Remarks at the global press conference, Foreign Press Centre, Washington, DC, 19 May. 
Commonwealth of Australia 2009, Defending Australia in the Asia-Pacific Century: Force 2030, Department of Defence, Canberra.

Friedman, G. 2008, The Next One Hundred Years, Doubleday, New York.

Gates, R. M. 2009, 'A balanced strategy: reprogramming the Pentagon for a new age', Foreign Affairs, vol. 88, no. 1 (January-February), pp. $28-40$.

Kagan, R. 2008, The Return of History and the End of Dreams, Knopf, New York.

Mearsheimer, J. 2001, The Tragedy of Great Power Politics, Norton, New York.

Obama, B. 2009, Remarks by the President on a new beginning, Cairo University, Cairo, Egypt, 4June 2009, <http://www.whitehouse.gov/the press_office/Remarks-by-the-President-at-Cairo-University-6-04-09/>

Osbourne, M. 2007, The Paramount Power, The Lowy Institute, Sydney, $<$ http://www.lowyinstitute.org/Publication.asp?pid=370>

White, H. 2008a, 'Australia in Asia: exploring the conditions for security in the Asian century', in D. I. Shambaugh and M. B. Yahuda (eds), International Relations of Asia, Rowan and Littlefield, Lanham, Ml., pp. 215-33.

2008b, 'Why war in Asia remains thinkable', Survival, issue 6 (December), pp. 85-104, <http://www.informaworld.com/smpp/b=al $\mathrm{l} \sim$ content $=\mathrm{t} 713659919 \sim \mathrm{tab}=$ issueslist $\sim$ branches $=50-\mathrm{v} 5050>$

Yueh, L. 2009, Law and Economics of Globalisation, Elgar, United Kindom. Zakaria, F. 2008, The Post American World, Norton, New York.

\section{Endnotes}

1. Four notable examples are Zakaria (2008); Kagan (2008); Bell (2008); CIA (2008).

2. See, for example, Mearsheimer (2001).

3. This argument is explored in Yueh (2009).

4. See also Friedman (2008).

5. See an interesting essay by Castles (2008).

6. For the latest example, see Obama (2009).

7. For a fuller account of this view of Asia's recent strategic history, see White (2008b).

8. For further exploration of these issues, see White (2008a). 